\title{
METACOGNITION IN ENTREPRENEURS: PSYCHOMETRIC DIAGNOSTIC ASSOCIATED TO AGE AND SEX ${ }^{1}$
}

\author{
Raimundo Nonato Lima Filho ${ }^{2}$ \\ Adriano Leal Bruni ${ }^{3}$
}

http://dx.doi.org/10.1590/1413-2311.178.67690

\begin{abstract}
The aim of this study was to identify elements that show the influence of the age and sex variables in the metacognitive level of professionals. Survey participants were 851 professionals registered in Bahia's Regional Administration Council who own their own businesses. Two validated psychometric instruments were used: Metacognitive Awareness Inventory (MAI) and the Metacognitive Activities Inventory (MCA-I). The hypothesis held that the respondent's age and sex influence their Metacognitive Profile. From the Structural Equation Modeling, the results indicate that the sex variable showed no significant relationship to the Metacognitive Profile. The implications of this study provide empirical conclusions that can aid entrepreneurs, companies, higher education institutions to understand the metacognitive aspects that influence the entrepreneur's behavior more systematically. Empirically, these results contribute so that the participating drivers of this study, as they develop metacognitive aspects, acquire a competitive advantage in their entrepreneurial performance.
\end{abstract}

Key-Words: Age. Sex. Metacognition. Entrepreneurs. Structural Equation Modeling.

\section{METACOGNIÇÃO EM EMPREENDEDORES: DIAGNÓSTICO ASSOCIADO A IDADE E SEXO}

\section{RESUMO}

O objetivo principal deste estudo foi levantar elementos que evidenciam a influência das variáveis idade e gênero no nível metacognitivo de profissionais. Participaram do survey 851 profissionais cadastrados no Conselho Regional de Administração da Bahia e que possuem negócio próprio. Foram utilizados dois instrumentos psicométricos validados: Inventário de Consciência Metacognitiva (MAI) e o Inventário de Atividades Metacognitivas (MCAi). As hipóteses defendiam que a idade e gênero do respondente influenciam o seu Perfil Metacognitivo. A partir da Modelagem de Equações Estruturais os resultados indicaram que a variável gênero não apresentou relação significativa para o Perfil Metacognitivo. As implicações desta pesquisa oferecem conclusões empíricas que podem ajudar

\footnotetext{
${ }^{1}$ Recebido em 07/09/2016; aprovado em 18/07/2017.

${ }^{2}$ Faculdade de Ciências Aplicadas e Sociais de Petrolina - rnlfilho@gmail.com.

${ }^{3}$ Universidade Federal Da Bahia - albruni@gmail.com.
} 
empreendedores, empresas, instituições de ensino superior a entender mais sistematicamente os aspectos metacognitivos que influenciam o comportamento empreendedor. Empiricamente, estes resultados contribuem para que os drivers participantes desta pesquisa ao desenvolver os aspectos metacognitivos, adquirem um diferencial competitivo na sua atuação empreendedora.

Palavras-chave: Idade. Gênero. Metacognição. Empreendedores. Modelagem de Equações Estruturais.

\section{METACOGNICIÓN EN EMPREENDEDORES: DIAGNOSTICO ASSOCIADO A EDAD Y SEXO}

\section{RESUMEN}

El objetivo de este estudio fue identificar los elementos que muestran la influencia de las variables de edad y sexo en el nivel metacognitivo de profesionales. Los encuestados fueron 851 profesionales inscritos en el Consejo de Administración Regional de la Bahía que son dueños de sus propios negocios. Se utilizaron dos instrumentos psicométricos validados: Inventario de la conciencia metacognitiva (MAI) y el Inventario de actividades metacognitivas (MCA-I). La hipótesis sostiene que la edad del entrevistado y el género influyen en su perfil de Metacognitiva. Del modelaje de ecuaciones estructurales, los resultados indican que la variable género no mostró una relación significativa con el perfil Metacognitiva. Las implicaciones de este estudio proporcionan conclusiones empíricas que pueden ayudar a empresarios, empresas, instituciones de educación superior para comprender los aspectos metacognitivos que influyen en el comportamiento de los empresarios de manera más sistemática. Empíricamente, estos resultados contribuyen de manera que los pilotos participantes de este estudio, a medida que desarrollan aspectos metacognitivos, adquieren una ventaja competitiva en su rendimiento empresarial.

Palabras clave: Edad. Género. La metacognición. Los empresarios; Modelos de Ecuaciones Estructurales.

\section{INTRODUCTION}

Metacognition is the ability to think about one's own thought, or even more, the act of assessing the thought of our own thoughts. Metacognition allows control over an action in a cognitive, emotional or motor level-object, allowing a manipulation of cognition elements to achieve the purpose of controlling it (PEIXOTO, 2007; BOYER, 2015). through this system, people can explore their own thinking strategies, having the autonomy and responsibility for building their own knowledge (ANDRETTA et al., 2010; BARREIRO, 2014; LIMA FILHO; BRUNI, 2014).

Metacognition is a possible strategy to turn knowledge into professional conduct

REAd | Porto Alegre - Vol. 23 - No Especial - Dezembro 2017 - p. 345-370 
(STEDILE; FRIENDLANDER, 2003; LIMA FILHO; BRUNI, 2015), since thinking about the thought process and establishing strategies to assist this process, maximizes the individuals potential in solving problems, indispensible characteristic for an entrepreneur.

International researches involving metacognition have grown substantially in the last years (SCHLEIFER; DULL, 2009; HART, 2014; PLUMLEE; RIXOM; BRETT, 2015), using opinion survey (KRAMARSKI et al., 2001) or experimental (KORNELL; METCALFE, 2006) researches. There are several contexts in which metacognition has been studied: Mathematics (KRAMARSKI; MIZRACHI, 2006; CARR; BIDDLECOMB， 1998; KRAMARSKI et al., 2001), Science (CONNER; GUNSTONE, 2004; OTERO, 1998), Economy (GRIMES, 2002), Psychology (METCALFE; STERNBERG, 1998), Chemistry (SANDÍ-URENÃ; COOPER; STEVENS, 2010) and English Language-Writing (SITKO, 1998). Various types of cognitive activities have been the focus of research about metacognition: for example, writing (ZIMMERMAN; KITSANTAS, 2002), reading comprehension (WILEY; GRIFFIN; THIEDE, 2005; MAKI, 1998), memory (THIEDE; ANDERSON, 2003), studies (KORNELL; METCALFE, 2006; WINNE; HADWIN, 1998; PRESSLEY et al., 1998) and problem solving (KRAMARSKI et al., 2001; DOMINOWSKI, 1998; DAVIDSON; STERNBERG, 1998). There are studies, also, about the numerous metacognitive impact factors (THIEDE; ANDERSON, 2003) and a how metacognition affects other variables related to the learning process (KORNELL; METCALFE, 2006).

Some studies involving metacognition focus on only one aspect; for example, the influence of age and sex (SHARMA; LAROIYA, 2008), the metacognitive knowledge (WHITE; FREDERIKSEN, 2005), the metacognitive monitoring (VADHAN; STANDER, 1994), the metacognitive control (ROSS et al., 2006) or a combination of these, referred as metacognitive processes or strategies (KRAMARSKI et al., 2001). These studies were conducted in realistic settings, such as classrooms (VEENMAN; VERHEIJ, 2001; NIETFELD et al., 2005), or in Education or Psychology laboratories (JANG; NELSON, 2005; SERRA; DUNLOSKY, 2005). These investigations contributed with the use of dynamic methods applied to the reality of the classroom and the impacts of these studies are in the presentation of results, that point metacognition as an indispensable item in the dynamics of "thinking".

In this conjuncture, the perspective of examining in this study arises, if the age or sex can affect the metacognitive level of an individual, intending to answer the following research problem: what is the relationship of the age and sex variables of professional entrepreneurs 
with their metacognitive level?

Metacognition is a theme that is currently in evidence and permeates various fields, like Psychology, Education, Sociology, and also Administration, having become the object of many studies around the world (SCARPATI, 2010). However, the literature about metacognition in entrepreneurs is scarce and although there are few international studies involving these issues (CHO, 2012), the bias that this study aims to achieve is unprecedented in the national context.

This study, therefore, contributes with the discussions involving personal variables of a subject such as age and sex through the analysis of his relation with the metacognitive level. As these relations are diagnosed with greater emphasis in the sample examined, the evidences will contribute to a specific direction in the formation of professional entrepreneurs.

\section{REVIEW OF RELATED LITERATURE}

The interest of studies involving entrepreneurship has shown substantial growth in the last years. This growth of entrepreneurship, as a research field, is evident in terms of number of researchers, articles, magazines and other types of publications. Entrepreneurs are studied from different perspectives. Cunningham e Lischeron (1991) identified six main schools of thought that study the entrepreneurial characteristics. The Great Persons School understands the entrepreneur as a person who was born with intuition, energy, persistence and self-esteem. The classic school highlights entrepreneurship with innovation, creativity and discovery. Yet administration school describes the entrepreneur as he who organizes, owns, manages and assumes the risk. In turn, the leadership school identifies the entrepreneur as the one who motivates, guides and leads. The intrapreneurship focuses on skilled managers in complex organizations. And finally, the psychological school that highlights the entrepreneurs as individuals with values and biases.

The empirical studies that follow the premises of the psychological school have shown greater prominence compared to the other schools (McCLELLAND, 1987; GUROL; ATSAN, 2006). These studies focus on identifying the personality characteristics that an individual has, and that this research aims to highlight, relating age and sex with the metacognitive level.

According to Haynie et al. (2010), metacognition is like a lens that allows an individual to see strategies that stimulate the entrepreneur process. Besides that, these authors claim that it is also up to metacognition the mental adaptation capability in uncertain and dynamic

REAd | Porto Alegre - Vol. 23 - No Especial - Dezembro 2017 - p. 345-370 
environments, required characteristic in an entrepreneur. This study examined the metacognitive aspects and the entrepreneurial perspective, concluding that metacognition promotes a cognitive adaptability, which in turn, improves the performance of certain entrepreneurial activities.

Urban (2012) states that metacognition is a cognitive process that serves to organize knowledge, tasks and situations, in order to promote effective and adaptive cognitive functioning, especially in complex and dynamic environments. While Masoumi Gazorkhani, Mashhadi and Yousefi (2014) state that metacognition is a tool that optimizes personal skills, attitudes and behavior.

Studies involving the entrepreneurial discussion with other variables, besides (meta)cognitive perspective, can be highlighted. Thomas, Bonura, Taylor and Brunyé (2012) developed a study that involved three experiments that analyzed the influence of age in the metacognitive monitoring in 50 participants, being 25 young adults and 25 more mature adults. In each experiment, a variable was modified (memory, identity and spacial location). In all of the experiments, the authors concluded that the age is a variable that directly affects the metacognitive profile.

Chisholm (1999) researched the sexs role in metacognition and in critical thinking of high school students. This study concluded through the application of a simple regression, that the sex affects significantly the metacognitive posture of the research participant, with and odds ratio of 0,14 , that is, the female sex has $14 \%$ more of a chance to develop metacognitive aspects compared to the male sex. This study analyzed other aspects, such as critical thinking and the respondent's school year; however, reserving comments to the sex variable, because only this variable is related to the purpose of this study.

Several other research points could converge to the entrepreneurial thematic, however, only quoting the (meta)-cognitive aspects, of age and sex, as these are the variables that will be studied in the empirical part.

\section{PROCEDURE METHODS}

\subsection{PARTICIPANTS}

The sample collected was raised by the accessibility criteria and the study of the eventual relation between the Metacognitive Profile, age and sex was conducted through the 
analysis of a sample composed of professional entrepreneurs from Bahia.

The data collection was executed from the application of an electronic questionnaire through Google Docs, provided by the CRA-BA and the sample was composed of 851 entrepreneurs.

\subsection{DATA COLLECTION PRE-TEST APPLICATION INSTRUMENT}

A pre-test was conducted for the instrument's validation and initial observation of the obtained data`s behavior utilizing the content validity. According to Haynes, Richard and Kubany (1995), the content validity aims to analyze the level of relevance a representativity of an assessment tool. It is considered as an appreciation of an instrument by different consultants, in order to validate if the instrument covers disparate conjectures of the object.

Emphasizing, that prior to the completion of the final research, a pre-test was conducted in the city of Senhor do Bonfim/BA. This city was chosen, considering that that the use of respondents of the city of Salvador/BA in this stage could impede the participation of respondents willing to contribute with the final study. The chosen city is located in the interior of the state, not having any specificities for its adoption, and was selected by the accessibility criteria. Possible differences of profiles between the pre-test and final test participants in this stage are not relevant, since there was the same requirement in the selection: higher education registered in the Regional Administration Council and manages a business.

The pre-test was divided in two stages. In the first stage, the subjects answered individually the research questionnaire. Subsequently, after filling out the questionnaire, the subjects participated in focus group type meeting that lasted about 40 minutes, where their perceptions and feelings related to the stimulation in the survey were expressed and their opinions about the questionnaire utilized, commenting on the suitability of the instrument time of application and each question was widely discussed, clarifying possible doubts regarding the terms and proper replacement in order to make the instrument comprehensible. After all the considerations, the questionnaire was adjusted for the final implementation.

\subsection{HYPOTHESIS TEST}

In order o answer the questionnaire of this study, hypotheses were proposed in order to conduct the empirical verification of the defined objective aligned to the investigated 
problem. Two hypotheses guided the methodological design of this study.

The first hypothesis, designated $\mathrm{H}_{1}$, defends that the greater the age of the respondent, the lower their metacognitive level will be.

Older adults perform cognitive tasks and use efficient strategies less often compared to younger adults. In a recent study, the results were analogous. Thomas et al. (2012) analyzed the metacognitive performance among younger and older adults. The authors conducted three experiments and concluded that the more mature adults underperformed compared to the younger adults.

Another survey also analyzed the influence of age on the metacognitive level (CAVALLINI; PAGNIN; VECCHI, 2002), which supports the use of this hypothesis.

The second hypothesis $-\mathrm{H}_{2}$ - establishes that there are significant differences in the metacognitive level presented between men and women.

Men and women clearly differ in certain psychological areas. According to Buss (1995), the differences between the sexs are not artificial or unstable. In all the other areas, the sexs are expected to be psychologically similar, although, studies that involve the cognitive perspective showed differences in this context (HALPERN, 2000).

A study by Chisholm (1999) analyzed the sex's role and metacognition in critical thinking of high school students. The results showed that the respondents sex is a significant predictor in the investigated relationship, and that women show a higher metacognitive skill.

In contrast, a study conducted by Fitzpatrick (1994) analyzed the influence of metacognition in mathematic problem solving and considered some covariates in this relationship, amongst them, the respondent's sex. In this study significant differences were not found between sexs. Although this result may not be aligned to the proposed hypothesis, it is necessary, nevertheless, to show divergent results, because the intention, in this subtopic, is to demonstrate that there are studies that are interested and analyze the same constructs. The results are the fruit of an analysis, that can undergo diverse interventions and will not necessarily repeat in this study.

This article intends to analyze the influence of sex in the metacognitive level in a simplified manner, understanding it as male or female. However, it seems fit to recognize that several perspectives involving sex discussion exist, but this study does not intend to address.

The presentation of the studies above intends to authenticate and give sustainability to the use of the hypotheses in this research. In order to test the hypotheses, two sets of questions were used, presented in a single type of questionnaire. Presented in the first set the 
Metacognitive Awareness Inventory by Schraw e Dennison (1994), the second set is composed of Metacognitive Activities Inventory developed by Cooper, Sandí-Ureña and Stevens (2008).

The original psychometric instruments were not adopted, but those translated and validated in the Portuguese language by Lima Filho (2013), which were presented without the label, so that the respondents didn't know they were testing their metacognitive level.

\subsection{DATA COLLECTION INSTRUMENT}

The data collection instrument used is the self-administered type, that approaches questions related to the object of this study: identification of the metacognitive perspective. Emphasizing that the questionnaires aim to identify the predominant metacognition profiles of each respondent, presented in a five point Likert scale. Thus, there are no answers that indicate right/wrong or best/worst patterns.

The first set of the research is the Metacognitive Awareness Inventory (MAI) that was developed by Schraw and Dennison and published in the 19th edition of Contemporary Educational Psychology in 1994. The aim of these studies was to develop a metacognitive inventory easy to apply to juveniles and adults.

Pintrich, Wolters and Baxter (2000) and Cooper (2004) conducted a statistical analysis of the MAI which proved to be an excellent metacognitive knowledge measurer. Pintrich, Wolters and Baxter (2000) conducted two exploratory factor analysis (EFA), using university students. These authors identified a knowledge scale (internal consistency amounting to 0,88 ) and an adjustment scale (internal consistency amounting to 0,91). Cooper (2004) also described that the reliability of the internal consistency of the MAI, in his study, varied from 0,93 to 0,88 , with a significant relationship between the knowledge and adjustment factors. Both researches concluded that the MAI provides a reliable metacognitive awareness assessment. Starting from the contributions of these researches, this study will use the term "Metacognitive Awareness" as a MAI construct, presented in Table 1, the MAI translated and validated by Lima Filho (2013).

The second set is the Metacognitive Activities Inventory (MCAi) that was developed by Cooper, Sandí-Ureña and Stevens (2008) and was published in the 9th edition of the Chemistry Education Research Practice. This instrument aims to provide educators a tool that allows a deeper comprehension of how a subject perceives his abilities to solve problems and 
activities.

Table 1 - Metacognitive awareness inventory

\begin{tabular}{|ll|}
\hline 1. & I put myself in rhythm while I am learning so I can have enough time. \\
2. & I understand my strong and weak intellectual points. \\
3. & I think about what I really need to know before starting a task. \\
4. & I know how well I did when I finish a task. \\
5. & I know what kind of information is more important to learn. \\
6. & I am good in organizing information. \\
7. & I know what the teacher expects me to learn. \\
8. & I am good at remembering information. \\
9. & I have control over how much I learn. \\
10. & I ask myself questions about the subject before starting to study. \\
11. & I think about various ways to solve a problem and choose the best one. \\
12. & I am a good judge to know how I understand things. \\
13. & I carefully read the instructions before starting a task. \\
14. & I organize my time to better accomplish my goals.
\end{tabular}

Source: Lima Filho (2013).

The original instrument was performed using reliable and validated criteria. The reliability was assessed by Cronbach's alpha test (level of 0,91) and the validity was examined through the construct validity and content. The MCAi showed a 0,53 Pearson Correlation coefficient, with a significance level of $0,01 \%$; the analysis of the average variance showed to be statistically different $(0,015)$, allowing the validation of this instrument, presented in Table 2, the MACi translated and validated by Lima Filho (2013).

Table 2 - Metacognitive Activities Inventory

\begin{tabular}{l}
\hline 15. I read the enunciation of a problem carefully to understand and determine what the goal. \\
16. I separate the enunciation's information and determine what is relevant. \\
17. Once the result is obtained, I verify if its according to what I expected. \\
18. I try to relate unknown problems with prior situations or solved problems. \\
19. I use graphic organizers (diagrams, flow charts) to better understand a problem. \\
20. I try to make sure my solution really answers the question. \\
21. \\
22.
\end{tabular}

Source: Lima Filho (2013).

It is also worth noting that these instruments were developed and validated following the assumptions of Psychometrics. Naturally, in one survey, only the individuals who placed themselves at the disposal of the research participate, which can indicate eventual biases in the answers (common method bias) and probable unrepresentability of the target population.

Kimura (2015) states that studies that involve variables of personal nature like REAd | Porto Alegre - Vol. 23 - No Especial - Dezembro 2017 - p. 345-370 
leadership, satisfaction and motivation, when the answers are raised by o data collection instrument, may usually indicate common-method variance (CMV).

However, recent studies indicate that CMV, even though being able to cause discrepancies in the data, the biases produced are minimal e don't substantially alter the results of a study (DIRK; MARCEL; LUTZ, 2009; SIEMSEN; ROTH; OLIVEIRA, 2010; SCHALLER; PATIL; MALHOTRA, 2015).

To circumvent the possibility of data limitation, it was aimed in this study to raise a large sample, adopting quantitative methods that ensure certainty in the data analysis. For this reason, Structural Equation Modeling was adopted, which are techniques and procedures used together to examine relationships between the variables. This dynamic is sustained adopting the Item Response Theory (IRT), which according to Pasquali and Primi (2003), from the latent traits of an individual presented through an evaluative instrument, it's possible to estimate its characteristics.

\subsection{ANALYSIS PLAN FOR THE DATA TREATMENT}

Aligned to the hypotheses of this study, the data treatment will be carried out in three phases. In the first, the data will be evaluated descriptively in order to characterize the respondents sample and examine the data distribution. In the second phase, nomological validity of the variables involved in this analysis will be tested, the last step of the construct validity, that is, proposed relationships between the constructs will be tested, and for that, the Partial Least Square of the Structural Equation Modeling (PLS-SEM) method was adopted, which allows the simultaneous analysis of dependency relationships, especially when the latent variables exert influence (exogenous) in a relationship and are influenced (endogenous) in the subsequent relationships (HAIR et al., 2005).

The sample size required for the PLS-SEM processing, according to Chin (1998), is five respondents per assertion or 5 to 10 times the number of influence relationships of the construct with a higher number of relationships. In this study, the data collecting instrument has 22 outputs, therefore, the sample size necessary to perform the data processing is 220 respondents, which was achieved by the data collection.

Finally, in the third phase the possible differences between the metacognitive level and sex of the respondents will be tested from the scores of this construct generated in PLS-SEM processing. In this stage, averages of equality test ' $t$ ' for independent samples of Student was 
used.

The theoretical model of this study intended to describe factors related to the metacognitive level. To this end, research instruments previously cited were used (table 1 and 2), consisting of 22 questions, the answers to which, at first, expect to be explained by seven factors: (a) Awareness of the Knowledge of Metacognitive Abilities and Strategies (CCME); (b) Awareness of Metacognition Regulation Strategies (CRME); (c) Metacognitive Activity Planning (AMEP); (d) Metacognitive Activity Monitoring (AMEM); (e) Metacognitive Activity Valuation (AMEA); (f) Age (IDAD) and finally, (g) Sex (GENE) of the respondent.

The initial model is postulated to be presented with the following factors:

a) Factor CCME - measured by questions 2, 5, 6, 7, 8,9 e 12;

b) Factor CRME - measured by questions 1, 3, 4, 10, 11, 13 e 14;

c) Factor AMEP - measured by questions 15 e 19;

d) Factor AMEM - measured by questions 16, 18, e 21;

e) Factor AMEA - measured by questions 17, 20 e 22;

f) Factor IDAD - a single question in which the respondent specifies his age in years;

g) Factor GENE - A single question in which the respondent specifies his sex (dummy variable -0 - male e 1 - female)

\section{DATA ANALYSIS}

\subsection{PHASE 1 - A DESCRIPTIVE ANALYSIS OF THE DATA}

A descriptive analysis of the data revealed that the sample was composed of 851 respondents, of which 59,11\% (503) were male and 40,89 (348) were female, with an average age of 37,8 years and deviation-pattern of 12,17 years.

The multivariate normality test of the data resulted in the kurtosis multivariate statistic PK of normalized Mardia ( $\mathrm{PK}=103,07$; sig=0,000). As expected, the distribution does not present multivariate normality since the data collected derived from ordinary scales (according to the research instrument).

Regarding the respondents age group distribution, 58,64\% of the respondents presented ages inferior to 38 years. The youngest respondents of this study are 22 years old (3 individuals) and the more mature are 72 years old ( 2 individuals). The multivariate normality 
test of the data resulted in the kurtosis multivariate statistic PK of normalized Mardia ( $\mathrm{PK}=78,77$; sig=0,000), therefore the distribution does not present multivariate normality.

Considering results according to sex, the average age of the women (average $=34,88$; Deviation-Pattern=0,398) is lower than that of men (Average=38,01; DeviationPattern=0,491) and the distribution frequencies are asymmetrically positive for both sexs, as shown in the histogram in Figure 1.

Table 3 - Composition of the sample by age

\begin{tabular}{ccc}
\hline & Frequency & Proportion \\
\hline Between 18 and 28 years of age & 201 & $23,62 \%$ \\
Between 29 and 38 years of age & 298 & $35,02 \%$ \\
Between 39 and 48 years of age & 185 & $21,74 \%$ \\
Between 49 and 58 years of age & 121 & $14,22 \%$ \\
Over 59 years of age & 46 & $5,41 \%$ \\
\hline \multicolumn{3}{c}{ Source: prepared by the author. }
\end{tabular}

Figure 1 - Age distribution by sex

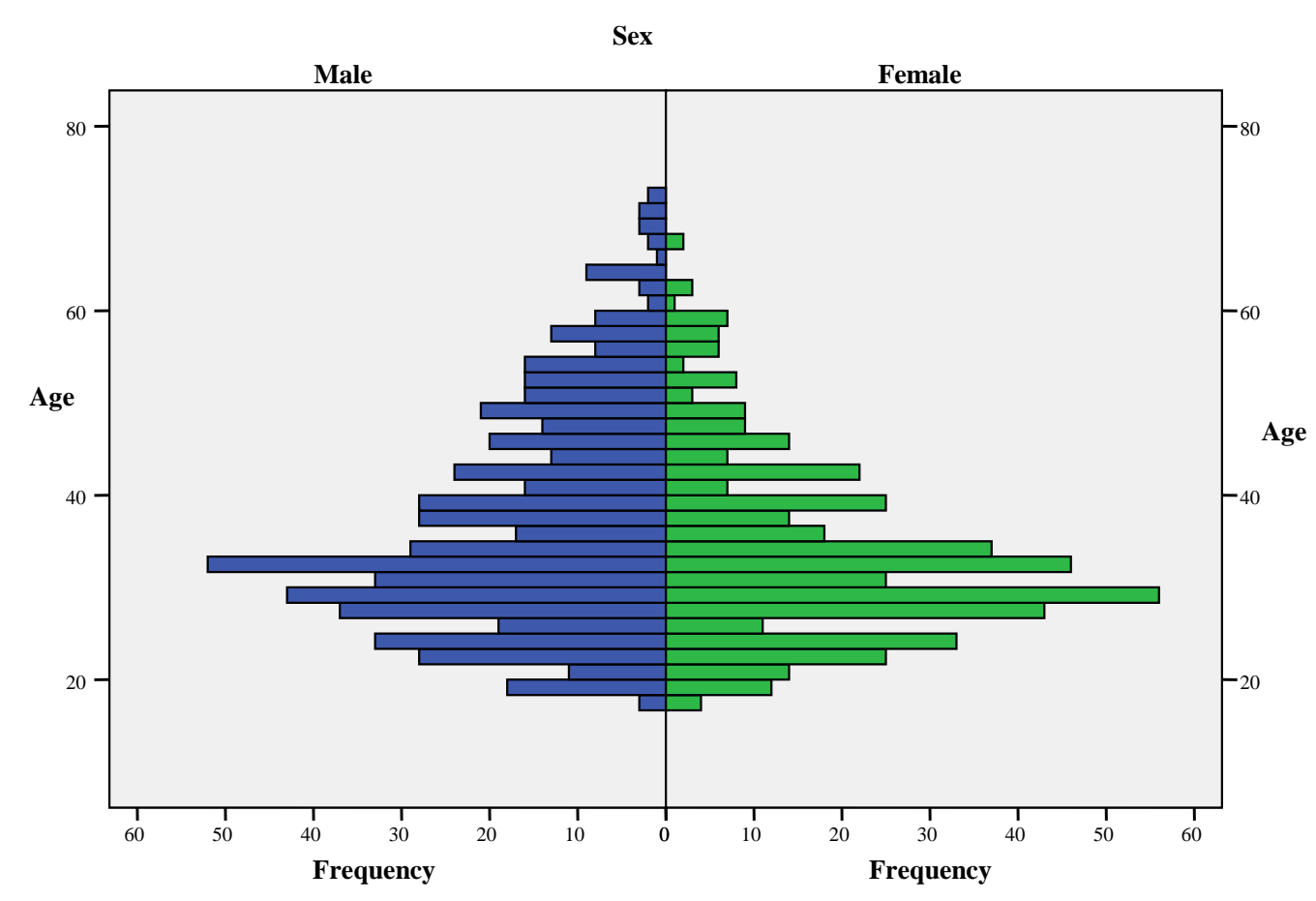

Source: prepared by the author.

\subsection{PHASE 2 - ANALYSIS OF THE RELATIONSHIPS PROPOSED IN THE STUDY}

The processing of the complete model involving the relationship dependencies between

REAd | Porto Alegre - Vol. 23 - No Especial - Dezembro 2017 - p. 345-370 
the proposed constructs in the study and among the observable indicators and the dimensions of these constructs with the multivariate statistic PLS-SEM via bootstrapping technique, processed with a sample of 851 respondents and 500 repetitions, resulted the 't' statistics of Student of Figure 2.

Figura 2 - Bootstrapping with a complete PLS-SEM Model

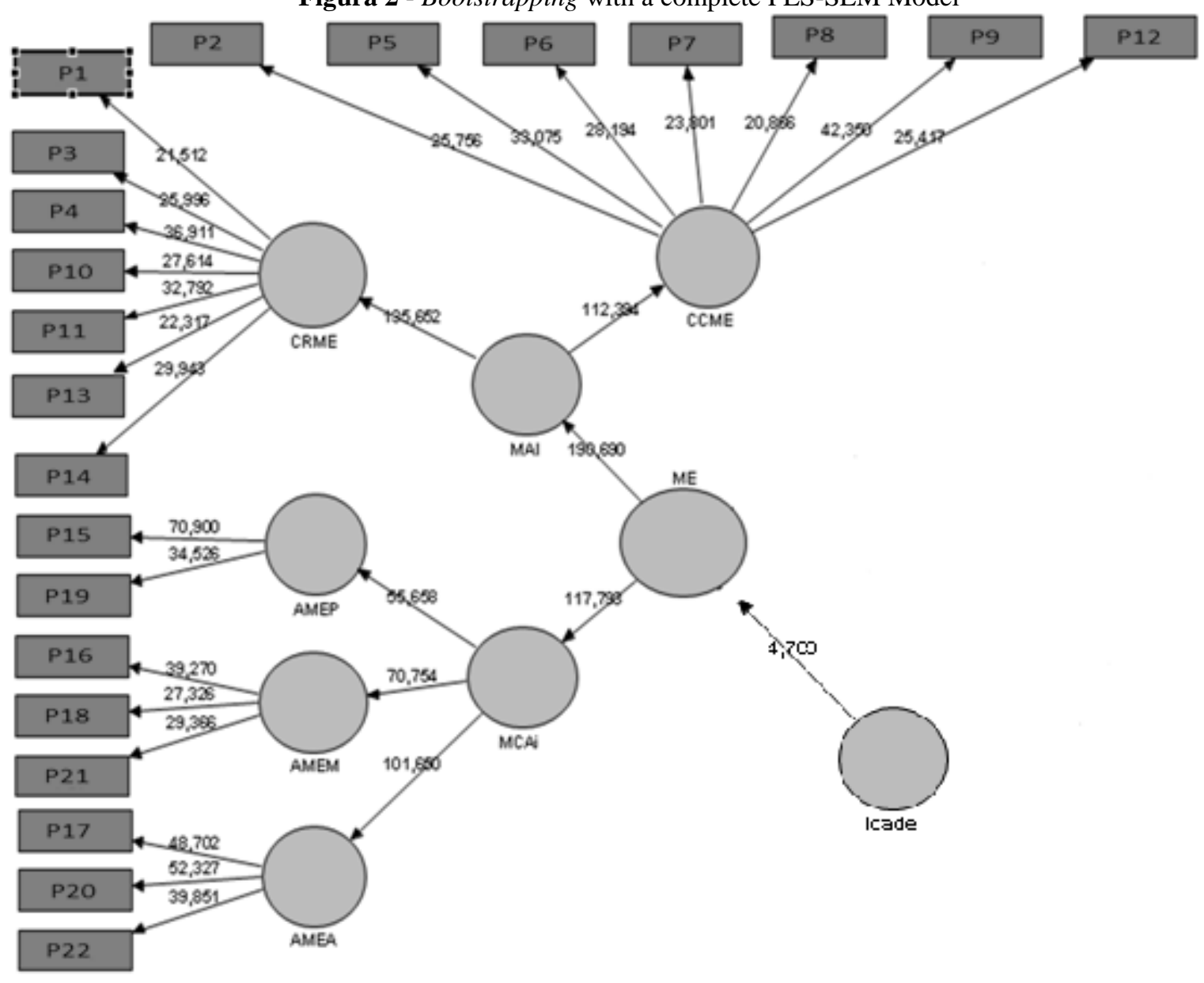

Source: prepared by the author.

As can be observed in Figure 2, the statistics t Student generated in bootstrapping for the loads of the mensuration model and the structural model present values much higher than the critical limit of 1,96, probably influenced by the size of the sample. These results show that the loads differ significantly from zero to the significance level of $5 \%$, which, combined to the magnitude of the obtained loads, evidencing the convergent validity of the mensuration model.

After the bootstrapping of the model, according to Table 4, it was required to obtain the estimates of the parameters, that is, the estimates of the coefficient that represent the direct REAd | Porto Alegre - Vol. 23 - No Especial - Dezembro 2017 - p. 345-370 
effects, variances and covariances of latent variables.

Table 4 - Coefficient estimate

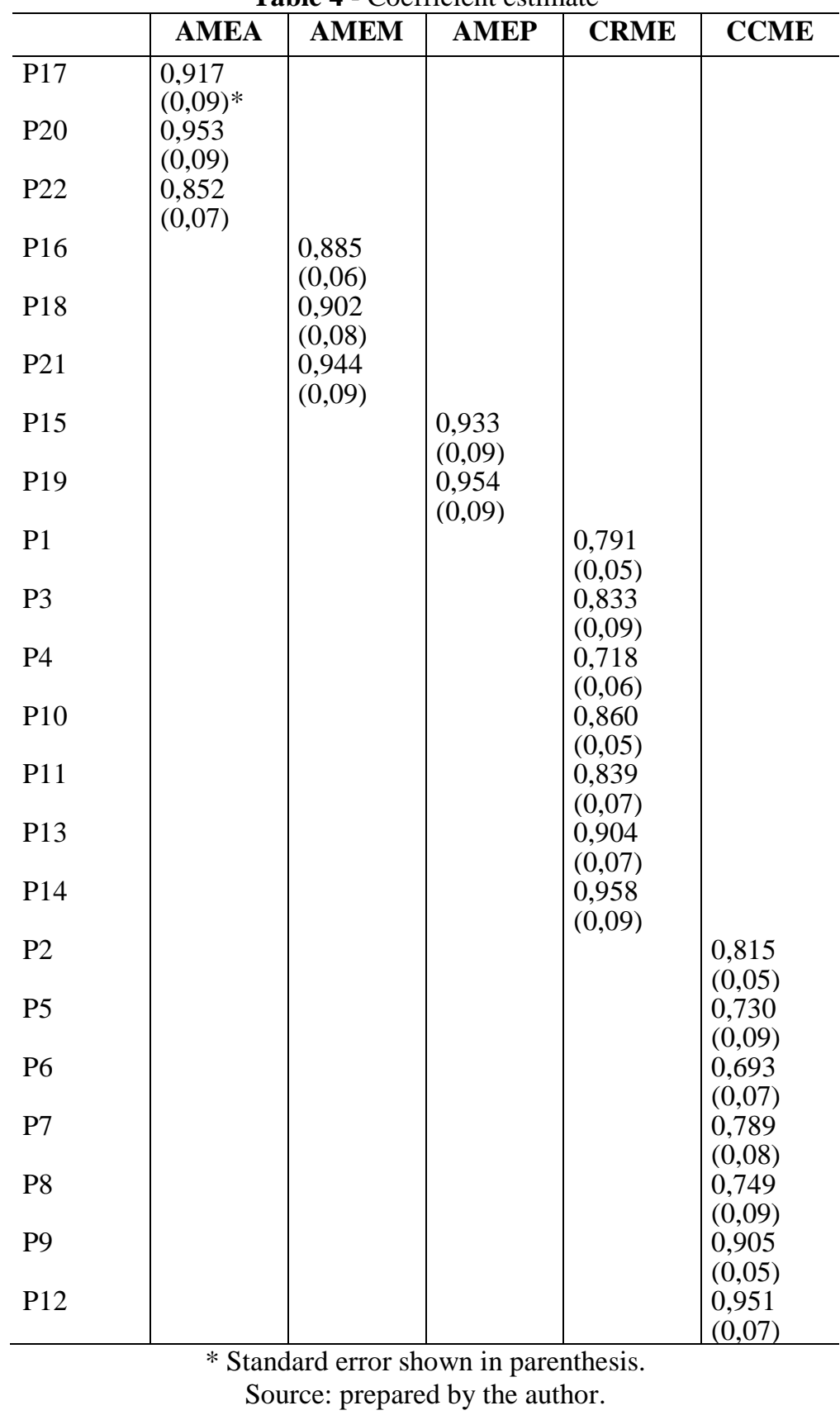

The correlation estimates between factors are of adjusted values, varying between 0,718 and 0,958 - which indicate the existence of discriminant validity of the latent variables in the construct conception. Subsequent to the bootstrapping, the estimated loads of the predictor's scale items in the latent variables presented significant values $(\mathrm{p}<0,000)$, rectifying that the used scale has convergent validity in assessing latent factors. Cronbach's alpha was of 0,893 suggesting the degree of reliability of the scale in measuring the differences between

REAd | Porto Alegre - Vol. 23 - No Especial - Dezembro 2017 - p. 345-370 
respondents and among latent variables (ANOVA: F = 11,837; Sig 0,000). The variance explained by the factorial solution was of $89,13 \%$, with a minimal commonality of 0,713 and a maximum of 0,895 . The index adjustment $\mathrm{KMO}=0,840$ and Bartlett's sphericity $=1433,22$ $(\mathrm{DF}=851$; Sig 0,000) were significant, indicating suitability for the following tests.

The discriminant validity was assessed parting from the comparison of the correlation loads between the dimensions AMEA, AMEM, AMEP, CCME and CRME (1st order) and Age, MAI, MCAi (2nd order) and ME (3rd order) and the AVE Roots indicated in bold on the correlation matrix's main diagonal shown in Table 5.

Table 5 - Correlation matrix between the dimensions and the research's constructs

\begin{tabular}{|c|c|c|c|c|c|}
\hline \multicolumn{6}{|c|}{ Panel A - 1st order measures of latent variables } \\
\hline & AMEA & AMEM & AMEP & CCME & CRME \\
\hline \multicolumn{6}{|c|}{ AMEA $\mathbf{0 , 7 9 3 1 8 2 2 ^ { \mathbf { a } }}$} \\
\hline AMEM & 0,630461 & $\mathbf{0 , 7 1 0 8 3}$ & & & \\
\hline AMEP & 0,55856 & 0,572275 & $\mathbf{0 , 8 0 0 3 0}$ & & \\
\hline CCME & 0,50193 & 0,485576 & 0,448528 & 0,64971 & \\
\hline CRME & 0,580162 & 0,576572 & 0,565943 & 0,626011 & 0,65924 \\
\hline C.C. & 0,835749 & 0,753667 & 0,780006 & 0,835828 & 0,842505 \\
\hline Average & 4,36208829 & 4,025187 & 3,968096 & 3,906253 & 4,00149 \\
\hline DP & 0,62107132 & 0,643481 & 0,800808 & 0,605006 & 0,621181 \\
\hline \multicolumn{6}{|c|}{ Panel B - 2nd order measures of latent variables } \\
\hline & Age & MAI & MCAi & ME & \\
\hline Age & 1 & & & & \\
\hline MAI & 0,153407 & 0,90139 & & & \\
\hline MCAi & 0,103932 & 0,687894 & 0,84951 & & \\
\hline $\mathrm{ME}^{*}$ & 0,143857 & 0,940319 & 0,889541 & 0,80703 & \\
\hline C. C & 1 & 0,881084 & 0,855805 & 0,908536 & \\
\hline Average & 35,96125 & 3,957007 & 4,169361 & 4,034458 & \\
\hline DP & 11,23632 & 0,552301 & 0,570189 & 0,521243 & \\
\hline
\end{tabular}

The data of Table 5 show that all the composite reliability measures (C.R.) are above the threshold of 0,70; and in each dimension the value of the AVE Root exceeds the value of the correlations between the constructs; thereon, the correlation between the indicators and their respective dimensions are stronger than the correlations between dimensions; therefore, the construct gathers discriminant validity. However, the correlations between these dimensions and the construct ME $(0,9403$ and 0,8895$)$ indicate that it is responsible for $88,4 \%$ 
and $79,1 \%$ of the MAI and MCAi ( $\mathrm{R}^{2}$ of correlation matrix) variability constructs, respectively. Therefore, these dimensions may be used to reflectively estimate the "Metacognition" (ME) construct. Furthermore, the complete model also gathers internal consistency and reliability to predict the proposed relationships.

With the aim to classify the surveyed by metacognitive profile, the following findings in the results of the survey of this study are presented, in Table 6 (by sex) and in Table 7 (by age).

Table 6 - Metacognition by Sex

\begin{tabular}{llcc}
\hline \multirow{2}{*}{ CRME } & & Male & Female \\
\cline { 2 - 4 } & Average & 3,9701 & 4,0111 \\
\hline CCME & Average & 0,6203 & 0,5988 \\
\cline { 2 - 4 } & Deviation pattern & 0,5948 & 0,5851 \\
\hline AMEP & Average & 3,8580 & 3,8326 \\
\cline { 2 - 4 } & Deviation pattern & 0,8889 &, 7858 \\
\hline AMEM & Average & 3,9263 & 3,9014 \\
\cline { 2 - 4 } & Deviation pattern & 0,7110 & 0,7042 \\
\hline AMEA & Average & 4,3673 & 4,3751 \\
\cline { 2 - 4 } & Deviation pattern & 0,6277 & 0,5584 \\
\hline
\end{tabular}

Source: prepared by the author.

Parting from the results of table 6, it can be noted that concerning Metacognitive Awareness, the women presented higher averages in Awareness of the Knowledge of Metacognitive Abilities and Strategies (CCME), that involves the declarative knowledge, procedural and conditional, as in the Awareness of Metacognition Regulation Strategies (CRME), that involves the planning, information management, monitoring, depuration and evaluation characteristics. Concerning Metacognitive Activities, the men stand out in the Metacognitive Activity Monitoring (AMEM) construct, which is an activity that evaluates the decisions during problem solving and in Metacognitive Activity Planning (AMEP), which is an activity that analyses the measures taken before the problem solving. In turn, the women stand out in the Metacognitive Activity Valuation (AMEA) construct, which is an activity that involves actions taken after the problem solving. It can be concluded, therefore, that while men posses an increased focus on the stages before and during the decision making, the women are more focused on the results that these decisions generate. 
The results of the $t$ and chi-square tests of tables 6 and 7 presents desirable significance levels, which corroborates the acquiescence of the indicated results of this topic.

In all Metacognitive levels, whether in constructs that involve Metacognitive Awareness (CRME and CCME) or those involving Metacognitive Activities (AMEP, AMEM and AMEA), it is noticeable, as shown in Table 5, that metacognition is stimulated by respondents age advancement.

Table 7 - Metacognition by age

\begin{tabular}{llccccc}
\hline & & $\mathbf{1 8}$ to $\mathbf{2 8}$ & $\mathbf{2 9}$ to 38 & $\mathbf{3 9}$ to $\mathbf{4 8}$ & $\mathbf{4 9}$ to 58 & Above 59 \\
& & years of & years of & years of & years of & years of \\
& & age & age & age & age \\
\hline \multirow{2}{*}{ CRME } & Average & 3,8913 & 3,9383 & 4,0281 & 4,1951 & 4,3079 \\
\cline { 2 - 7 } & Deviation pattern & 0,6318 & 0,5992 & 0,6113 & 0,5238 & 0,5665 \\
\hline CCME & Average & 3,8285 & 3,9098 & 3,9495 & 4,0360 & 3,8921 \\
\cline { 2 - 7 } & Deviation pattern & 0,5892 & 0,5950 & 0,6203 & 0,4957 & 0,6294 \\
\hline \multirow{2}{*}{ AMEP } & Average & 3,7474 & 3,7854 & 3,9318 & 4,0488 & 4,1000 \\
\cline { 2 - 7 } & Deviation pattern & 0,8995 & 0,8156 & 0,8257 & 0,7903 & 0,8160 \\
\hline \multirow{2}{*}{ AMEM } & Average & 3,8454 & 3,8763 & 3,9512 & 4,0786 & 4,1037 \\
\cline { 2 - 7 } & Deviation pattern & 0,6927 & 0,7005 & 0,7353 & 0,6843 & 0,7276 \\
\hline \multirow{2}{*}{ AMEA } & Average & 4,3299 & 4,3434 & 4,3737 & 4,4824 & 4,5556 \\
\cline { 2 - 7 } & Deviation pattern & 0,6657 & 0,5866 & 0,5695 & 0,5107 & 0,5270 \\
\hline
\end{tabular}

Source: prepared by the author.

\subsubsection{Hypothesis Test}

The proposition of the hypothesis $\mathrm{H}_{1}$ was to evaluate if the greater the age of the respondent, the lower the metacognitive level would be. With this finality, a null hypothesis was formulated:

$\mathrm{H}_{10}$ : There is no relationship between age and metacognition

It is observed that age significantly influences the metacognitive level $\left(\beta_{1}=0,144 ; \mathrm{t}=\right.$ 4,769 ; sig= 0,000); however, the explanation of the variability of this age construct was low, equal to $2,10 \%$.

Despite the low explanatory problem and from the analysis of this data, the Age variable presented significant effect compared to the answers (metacognition), it can be inferred, with p-value of 0,000 , which allows the nullity hypothesis $\left(\mathrm{H}_{10}\right)$ rejection.

These results are aligned with the studies carried out by Cavallini, Pagnin and Vecchi REAd | Porto Alegre - Vol. 23 - No Especial - Dezembro 2017 - p. 345-370 
(2002), Rai (2008), Jha (2010), Thomas et al. (2012), Lima Filho, Bruni and Amorim (2014). The research data presented a result in the opposite direction of that what was hypothesized. So the first hypothesis of this study, demonstrated empirically in the following manner: 'the greater the age of the respondent, the higher their metacognitive level will be'.

The proposition of the $\mathrm{H}_{2}$ hypothesis was to analyze if the respondent's sex can influence their metacognitive level. With this purpose, the following null hypothesis was established:

$\mathrm{H}_{20}$ : There is no relationship between sex and metacognition;

To test this hypothesis, an independent sample test will be conducted, displayed in Phase 3 of this chapter.

\subsection{PHASE 3 - INDEPENDENT SAMPLE TEST}

Before the average equality test, a preliminary exam on the factorial scores generated in the PLS-SEM assessment according to the sex and their metacognitive level was executed. the distribution of these scores according to the averages and deviation patterns are shown on Table 8.

Table 8 - Scores by sex

\begin{tabular}{|c|c|c|c|}
\hline & & \multicolumn{2}{|c|}{ Sex } \\
\hline & & Male & Female \\
\hline Metacognitive & Average & $-0,0087$ & 0,0109 \\
\hline Level & Deviation Pattern & 0,0406 & 0,0471 \\
\hline
\end{tabular}

The values indicate that the female sex reveals a higher metacognitive level compared to men, although, it is necessary to verify if this difference is significant. The analysis of the normality score 'Metacognition' showed Kolmogorov-Smirnov measurements equal to $(\mathrm{KS}=1,162$; sig=0,134), which allows to accept the distribution as normal.

The results of the averages of equality test ' $t$ ' for independent samples of Student processed with the 'metacognition' scores according to sex are synthesized in Table 9.

As can be observed in Table 9, the differences in averages to the metacognitive level according to sex was not significant (Metacognition=-0,04146; sig=0,493). Therefore, considering the level of significance, there are no differences between the metacognitive level

REAd | Porto Alegre - Vol. 23 - No Especial - Dezembro 2017 - p. 345-370 
and the respondents sex; thus, the second null hypothesis is accepted. These results are aligned to the evidence found by Fitzpatrick (1994), who also did not find significant differences between men and women in the context of his study.

Table 9 - Averages test for independent samples

\begin{tabular}{lccccccc}
\hline Sex & $\mathbf{t}$ & df & $\begin{array}{c}\text { Sig. (bi- } \\
\text { caudal) }\end{array}$ & Average & $\begin{array}{c}\text { Deviation } \\
\text { Pattern }\end{array}$ & Superior & Inferior \\
\hline $\begin{array}{l}\text { Metacognition } \\
\text { (Male-Female) }\end{array}$ & $-0,686$ & 1050 & 0,493 & $-0,04146$ & 0,06040 & $-0,15998$ & 0,07707 \\
\hline
\end{tabular}

Source: prepared by the author.

\section{CONCLUSION}

This study had a research problem which had the intention of explaining the relationship of age and sex in entrepreneurs with their metacognitive level, This study also aimed to analyze the elements that could demonstrate this relationship.

Responding to the research problem and the proposed general objective, in the methodology conducted in this study, the conducted empirical tests confirmed the hypothesis effect of age in the respondents' metacognition, however, the hypothesis of the influence of sex on metacognitive level was not corroborated. Therefore, it was only observed that age is a factor that impacts metacognition, at least in the context comprehended in this research.

These results, may however, contribute to the professional qualification and updating of entrepreneurs, as these diagnostics from two psychometric instruments indicate specific paths of the limitations and inclinations that the participants of this study have in relationship to the Metacognitive Profile.

"The greatest discovery in my generation is that human beings can change their lives changing mental attitudes" (JAMES, 1890, p. 290). The ability to think about one's own thought, that is, a mental attitude that we have (metacognition) directly affects our lives. Specifically in this study, it was found that the age of an individual is a characteristic that significantly influences the Metacognitive Profile of entrepreneurs.

In the current social and market context, the specific knowledge and the acting of a professional specialist are no longer sufficient for the success of an entrepreneur, becoming a minimal pre-requisite. The differential are in the skills, talents, creative attitudes and in the ability to think and reflect by identifying opportunities and completing them. It is at this juncture that the metacognition stands, a characteristic that causes a competitive differential in 
the entrepreneurial context.

It is expected that this study has contributed with some portion of knowledge the research fields of entrepreneurship, as in the Cognitive Psychology field. In relation to metacognition in individuals related to entrepreneurship, no empirical study was conducted in a national context and few were have been developed in an international context.

Some important limitations of this study can be highlighted, which can be seen as opportunities for future research. The common method bias, even though this study adopted a large sample and robust statistical tests, a $26 \%$ average bias may be implied in the similarities among the constructs (DOTY; GLICK, 1998), as the respondent may not be totally honest in answering the self-administered instrument. The sample of this research was restricted to State of Bahia and selected through non-probability sampling, future studies could apply the instruments in other regional contexts and/or in 'non-professional' entrepreneurs, adopting probability sampling aspects, thus avoiding, a sample with the smallest endogeneity possible, to analyze the behavior of the constructs in the research's context and corroborate or refute the findings of this study.

\section{REFERENCES}

ANDRETTA, I.; SILVA, J. G. da; SUSIN, N.; FREIRE, S. D. Metacognição e aprendizagem: como se relacionam? Revista PSICO, v. 41, n. 1, p. 07-13, 2010.

BARREIRO, O. M. Cognitive ability, thinking styles, emotional intelligence, and their impact on academic performance. Tese de Doutorado (Doutorado em Psicologia). Walden University, 2014.

BOYER, B. L. Designing for learner metacognition and academic inquiry: an investigation of the stripling inquiry model. 2015. $59 \mathrm{f}$. Tese de Doutorado (Doutorado em Educação), CapellaUnivesity.

BUSS, D. M. Evolutionary psychology: A new paradigm for psychological science.

Psychological Inquiry, v. 6, p. 1-30, 1995.

CARR, M.; BIDDLECOMB, B. Metacognition in mathematics from a constructivist perspective. HACKER, D. J.; DUNLOSKY, J.; GRAESSER, A. C. (Eds.). Metacognition in educational theory and practice. Mahwah: Lawrence Erlbaum Associates, 1998. p. 69-91. CAVALLINI, E.; PAGNIN, A.; VECCHI, T. The rehabilitation of memory in old age: effects of mnemonics and metacognition in strategic training. Clinical Gerontologist, v. 26, n. 1/2, 
p. 125-141, 2002.

CHIN, W. W. The partial least squares approach for structural equation modeling.

MARCOULIDES, G. A. (Ed.). Modern methods for business research. Mahwah, N.J.:

Lawrence Erlbaum Associates, 1998. p. 295-336

CHISHOLM, J. M. The effects of metacognition, critical thinking, sex, and sex role identification on academic achievement in the middle years. 1999. $122 \mathrm{f}$. Tese de Doutorado (Doutorado em Psicologia), Universidade de Mount Saint Vincent.

$\mathrm{CHO}, \mathrm{Y}$. S. The impact of metacognition on entrepreneurial orientation: research-in-progress. Annual Meeting Southwest Decision Sciences, 43th, New Orleans/EUA, 2012.

CONNER, L.; GUNSTONE, R. Conscious knowledge of learning: accessing learning strategies in a final year high school biology class. International Journal of Science Education, v. 26, n.12, p. 1427-1443, 2004.

COOPER, S. S. Metacognition in the adult learner. Ogden UT: Weber State University, 2004.

COOPER, M. M.; SANDÍ-UREÑA, S.; STEVENS, S. Reliable multi method assessment of metacognition use in chemistry problem solving. Chemistry Education Research and Practice, v. 9, n. 1, p. 18-24, 2008.

CUNNINGHAM, J. B.; LISCHERON, J. C. Defining Entrepreneurship. Journal of Small Business Management, v. 29, n.1, p. 45-61, 1991.

DAVIDSON, E.; STERNBERG, R. J. Smart problem solving: how metacognition helps. HACKER, D. J.; DUNLOSKY, J.; GRAESSER, A. C (Eds.). Metacognition in educational theory and practice in metacognition in educational theory and practice. Mahwah: Lawrence Erlbaum Associates, 1998. p. 69-91

DIRK, T.; MARCEL, P.; LUTZ, H. Common Method Variance/Ursachen, Auswirkungen und Kontroll-möglichkeiten. Die Betriebswirtschaft, v. 69, n. 2, p. 123-146, 2009.

DOMINOWSKI, R. L. Verbalization and problem solving. HACKER, D. J.; DUNLOSKY, J.; GRAESSER, A. C. (Eds.). Metacognition in educational theory and practice. Mahwah: Lawrence Erlbaum Associates, 1998. p. 25-46

DOTY, D. H.; GLICK, W. H. Common methods bias: does common methods variance really bias results? Organizational Research Methods, v.1, n. 4, p. 374-406, 1998.

FITZPATRICK, C. C. Adolescent mathematical problem-solving: the role of mathematics knowledge, sex, metacognition, strategies, and beliefs. 1994. 274 f. Tese de Doutorado, Universidade de Columbia.

REAd | Porto Alegre - Vol. 23 - No Especial - Dezembro 2017 - p. 345-370 
GRIMES, P. W. The overconfident principles of economics student: an examination of a metacognitive skill. Journal of Economic Education, v. 33, n. 1, p. 15-30, 2002.

GUROL, Y.; ATSAN, N. Entrepreneurial characteristics amongst university students: some insights for entrepreneurship education and training in Turkey. Journal of Education \& Training, v. 48, n. 1, p. 25-38, 2006.

HAIR, J. F.; ANDERSON, R. E.; TATHAM, R. L.; BLACK, W. C. Multivariate data analysis. 5. Ed. New Jersey: Prentice Hall, 2005.

HALPERN, D. F. Sex differences and cognitive abilities. Mahwah, NJ: Erlbaum, 2000.

HART, J. Guided metacognition in instrumental practice. Music Educators Journal, v. 101, n. 2, p. 57-64, 2014.

HAYNIE, J. M.; SHEPHERD, D. A.; MOSAKOWSKI, E.; EARLEY, P. C. A situated metacognitive model of the entrepreneurial mindset. Journal of Business Venturing, v. 25, p. 217-229, 2010.

HAYNES, S.N.; RICHARD, D.C.S; KUBANY, E.S. Content validity in psychological assessment: afunctional approach to concepts and methods. Psychological Assessment, v. 7, n. 3, p. 238-247, 1995.

JANG, Y.; NELSON, T. O. How many dimensions underlie judgments of learning and recall? Evidence from state-trace methodology. Journal of Experimental Psychology, v. 134, n. 3, p. 308-326, 2005.

JHA, K. K. Entrepreneurship characteristics of ginger cultivators in Nagaland. Environment and Ecology, v. 28, n. 3, p. 1586-1588, 2010.

KIMURA, H. Editorial. Revista de Administração Contemporânea, v. 19, n. 3, p. 1-5, 2015.

KORNELL, N.; METCALFE, J. Study efficacy and the region of proximal learning framework. Journal of Experimental Psychology: Learning, Memory, and Cognition, v. 32, n. 3, p. 609-622, 2006.

KRAMARSKI, B.; MEVARECH, Z. R.; LIEBERMAN, A. Effects of multilevel versus unilevel metacognitive training on mathematical reasoning. Journal of Educational Research, v. 94, n. 5, p. 292-300, 2001.

KRAMARSKI, B.; GUTMAN, M. How can self-regulated learning be supported in mathematical elearning environments? Journal of Computer Assisted Learning, v. 22, n. 1, p. 24-33, 2006.

LIMA FILHO, R. N. (2013). Empreendendo sobre o empreender e pensando sobre o

REAd | Porto Alegre - Vol. 23 - No Especial - Dezembro 2017 - p. 345-370 
pensar: um estudo sobre características empreendedoras e metacognição. Tese (Doutorado em Administração). 2013. 114 f. Universidade Federal da Bahia, Salvador. LIMA FILHO, R. N.; BRUNI, A. L. Metacognição e Empreendedorismo: Ser Empreendedor influencia atitudes Metacognitivas? Revista Gestão \& Regionalidade, v. 30, n. 89, p. 63-74, 2014.

LIMA FILHO, R. N.; BRUNI, A. L. Metacognição estimula características empreendedoras? Uma análise em estudantes e profissionais de Administração. Revista de Administração, Contabilidade e Economia, v. 14, n. 2, p. 427-450, 2015.

LIMA FILHO, R. N.; BRUNI, A. L.; AMORIM, R. J. R. The influence of age and sex on entrepreneurial behavior characteristics of students and professionals of Business Administration. African Journal of Business Management, v. 8, n. 21, p. 1019-1028, 2014. MAKI, R. H. Test predictions over text material. HACKER, D. J.; DUNLOSKY, J.; GRAESSER, A. C. (Eds.). Metacognition in educational theory and practice. Mahwah: Lawrence Erlbaum Associates, 1998. p. 117-144.

MASOUMI GAZORKHANI, A.; MASHHADI, H.; YOUSEFI, N. The effect of cognitive and metacognitive strategies teaching on learning of the students of Tarbiatmoalem of shahidrajayi of Qazvin. Kuwait Chapter of Arabian Journal of Business and Management Review, v. 3, n. 12, p. 96-104, 2014.

McCLELLAND, D. Characteristics of successful entrepreneurs. The Journal of Creative Behavior, v. 21, n. 3. p. 219-233, 1987.

METCALFE, J.; SHIMAMURA, A. P. Metacognition: knowing about knowing. Cambridge, MA: MIT Press, 1994.

NIETFELD, J. L.; CAO, L.; OSBORNE, J. W. Metacognitive monitoring accuracy and student performance in the postsecondary classroom. Journal of Experimental Education, v. 74, n. 1, p. 7-28, 2005.

OTERO, J. Influence of knowledge activation and context on comprehension monitoring of science texts. HACKER, D. J.; DUNLOSKY, J.; GRAESSER, A. C. (Eds.).

Metacognition in educational theory and practice. Mahwah: Lawrence Erlbaum Associates, 1998.

PASQUALI, L.; PRIMI, R. Basic theory of Item Response Theory - IRT. Avaliação Psicológica, v. 2, n. 2, p. 99-110, 2003.

PEIXOTO, M. A. P.; BRANDÃO, M. A. G.; SANTOS, G. Metacognição e tecnologia educacional simbólica. Revista Brasileira de Educação Médica, v. 31, n. 1, p. 67-80, 2007. 
PINTRICH, P. R.; WOLTERS, C. A.; BAXTER, G. P. Assessing metacognition and selfregulated learning. SCHRAW, G.; IMPARA, J. C. (Eds.). Issues in the measurement of metacognition, Lincoln, NE: Buros Institute of Mental Measurement, 2000. p. 43-97. PLUMLEE, R. D.; RIXOM, B. A.; ROSMAN, A. J. Training auditors to perform analytical procedures using metacognitive skills. The Accounting Review, v. 90, n. 1, p. 351-369, 2015 .

PRESSLEY, M.; VAN ETTEN, S.; YOKOI, L.; FREEBERN, G.; VAN METER, P. The metacognition of college studentship: a grounded theory approach. HACKER, D. J.; DUNLOSKY, J.; GRAESSER, A. C. (Eds.). Metacognition in educational theory and practice. Mahwah: Lawrence Erlbaum Associates, 1998. p. 347-363.

RAI, S. K. Indian Entrepreneurs: An empirical investigation of entrepreneur's age and firm entry, type of ownership and risk behavior. Journal of Service Research, v. 8, n. 1, p. 213$228,2008$.

ROSS, M.; GREEN, S.; SALISBURY-GLENNON, J.; TOLLEFSON. N. College students' study strategies as a function of testing: an investigation into metacognitive self-regulation. Innovative Higher Education, v. 30, n. 5, p. 361-375, 2006.

SANDÍ-UREÑA, G. S.; COOPER, M. M.; STEVENS, R. H. Enhancement of metacognition use and awareness by means of a collaborative intervention. International Journal of Science Education, v. 1, n. 3, p. 1-18, 2010.

SCARPATI, S. Developments in accounting education. The CPA Journal, v. 1, p. 10-13, 2010.

SCHLEIFER, L.; DULL, R. Metacognition and performance in the accounting classroom. Issues in Accounting Education, v. 23, n. 3, p. 339-367, 2009.

SCHALLER, T. K.; PATIL, A.; MALHOTRA, N. K. Alternative techniques for assessing common method variance: an analysis of the theory of planned behavior research.

Organizational Research Methods, v. 18, n. 2, p. 177-206, 2015.

SCHRAW, G; DENNISON, R. S. Assessing metacognitive awareness. Contemporary Educational Psychology, v. 19, July, p. 460- 47, 1994.

SERRA, M. J.; DUNLOSKY, J. Does retrieval fluency contribute to the underconfidence with practice effect? Journal of Experimental Psychology: Learning, Memory, and Cognition, v. 31, n. 6, p. 1258-1266, 2005.

SHARMA, D. D.; LAROIYA, S. C. A Comparative Analysis of Characteristics and Challenges of Male and Female Entrepreneurs in India. World Conference Proceedings of REAd | Porto Alegre - Vol. 23 - No Especial - Dezembro 2017 - p. 345-370 
Internacional Council for Small Business. 2008. Disponível em http://search.proquest.com/docview/192410184/fulltext/136953A556452184457/7?accountid $=14643$. Acesso em: 8 maio de 2012.

SIEMSEN, E.; ROTH, A.; OLIVEIRA, P. Common method bias in regression models with linear, quadratic, and interaction effects. Organizational Research Methods, v. 13, n. 3, p. 456-476, 2010.

SITKO, B. M. Knowing how to write: metacognition and writing instruction. HACKER, D. J.; DUNLOSKY, J.; GRAESSER, A. C. (Eds.). Metacognition in educational theory and practice. Mahwah: Lawrence Erlbaum Associates, 1998. p. 93-116.

STEDILE, N. L. R.; FRIENDLANDER, M. R. Metacognição e ensino de enfermagem: uma combinação possível? Revista Latino-Americana de Enfermagem, v. 11, n. 6, p. 792-799, 2003.

THIEDE, K. W.; ANDERSON, M. C. M. Summarizing can improve metacomprehension accuracy. Contemporary Educational Psychology, v. 28, n. 2, p. 129-160, 2003. THOMAS, A. K.; BONURA, B. M.; TAYLOR, H. A.; BRUNYÉ, T. T. Metacognitive monitoring in visuospatial working memory. Psychology and Aging,v. 27, n. 4, p. 1099$1110,2002$.

URBAN, B. A metacognitive approach to explaining entrepreneurial intentions.

Management Dinamics, v. 21, n. 2, p. 16-33, 2012.

VADHAN, V.; STANDER, P. Metacognitive ability and test performance among college students. The Journal of Psychology, v. 128, n. 3, p. 307-309, 1994.

VEENMAN, M. V. J.; ELSHOUT, J. J.; MEIJER, J. The generality vs. domain-specificity of metacognitive skills in novice learning across domains. Learning Instrumental, v. 7, n, 2, p. 187-209, 1997.

WHITE, B.; FREDERIKSEN, J. A theoretical framework and approach for fostering metacognitive development. Educational Psychologist, v. 40, n. 4, p. 211-223, 2005. WILEY, J.; GRIFFIN, T. D.; THIEDE, K. W. Putting the comprehension in metacomprehension. Journal of General Psychology, v. 132, n. 4, p. 408-428, 2005. WINNE, P. H.; HADWIN, A. F. Studying as self-regulated learning. HACKER, D. J.; DUNLOSKY, J.; GRAESSER, A. C. (Eds.). Metacognition in educational theory and practice. Mahwah: Lawrence Erlbaum Associates, 1998. p. 277-304.

ZIMMERMAN, B. J.; KITSANTAS, A. (Acquiring writing revision and self-regulatory skill through observation and emulation. Journal of Educational Psychology, v. 94, n. 4, p. 660- 
668, 2002.

REAd | Porto Alegre - Vol. 23 - No Especial - Dezembro 2017 - p. 345-370 